\title{
The Memory-Enhancing Effects of Hippocampal Estrogen Receptor Activation Involve Metabotropic Glutamate Receptor Signaling
}

\author{
Marissa I. Boulware, John D. Heisler, and Karyn M. Frick \\ Department of Psychology, University of Wisconsin-Milwaukee, Milwaukee, Wisconsin 53211
}

Our laboratory has demonstrated that $17 \beta$-estradiol $\left(\mathrm{E}_{2}\right)$ enhances hippocampal memory consolidation via rapid activation of multiple intracellular signaling cascades, including the ERK/MAPK cascade (Fernandez et al., 2008; Fan et al., 2010). However, the receptor mechanisms responsible for these effects of $\mathrm{E}_{2}$ remain unclear. In vitro, estrogen receptor $\alpha(\mathrm{ER} \alpha)$ signaling through metabotropic glutamate receptor 1a (mGluR1a) leads to ERK-dependent CREB phosphorylation (Boulware et al., 2005), suggesting that interactions between ERs and mGluR1a may be vital to the memory-enhancing effects of $\mathrm{E}_{2}$. As such, the present study tested the roles of classical estrogen receptors (ER $\alpha$ and $E R \beta)$ and mGluRla in mediating the effects of $E_{2}$ on hippocampal memory consolidation. Dorsal hippocampal (DH) infusion of ER $\alpha$ (PPT) or ER $\beta$ (DPN) agonists enhanced novel object recognition and object placement memory in ovariectomized female mice in an ERK-dependent manner, suggesting that these receptors influence memory by rapidly activating hippocampal cell signaling. Next, DH infusion of the mGluR1a antagonist LY367385 blocked the object and spatial memory facilitation induced by $\mathrm{E}_{2}$, PPT, and DPN, demonstrating that ER/mGluR1a signaling is critical for the memory-enhancing effects of $\mathrm{E}_{2}$. Finally, we show that $\mathrm{ER} \alpha$, $\mathrm{ER} \beta$, mGluR1, and ERK all reside within specialized membrane microdomains of the $\mathrm{DH}$, and that $\mathrm{ER} \alpha$ and $\mathrm{ER} \beta$ physically interact with mGluR1, providing a means through which ERs may activate mGluRs and downstream signaling. Together, these findings provide the first in vivo evidence demonstrating that $\mathrm{ER} / \mathrm{mGluR}$ signaling can mediate the beneficial effects of $\mathrm{E}_{2}$ on hippocampal memory consolidation.

\section{Introduction}

Although it has become well accepted that $17 \beta$-estradiol $\left(\mathrm{E}_{2}\right)$ elicits rapid effects on hippocampal signaling (Micevych and Christensen, 2012) and memory consolidation (Frick, 2012), the receptor mechanisms underlying these effects are poorly understood. Some evidence suggests that membrane-localized classical estrogen receptors (ERs; $\mathrm{ER} \alpha$ and $\mathrm{ER} \beta$ ) mediate these effects. In the hippocampus, both $\operatorname{ER} \alpha$ and $\operatorname{ER} \beta$ are localized to extranuclear sites, including the plasma membrane of dendritic spines and axons (Milner et al., 2001, 2005; Mitterling et al., 2010). Studies using specific $\operatorname{ER} \alpha$ and $\operatorname{ER} \beta$ agonists indicate that these ERs modulate hippocampal expression of synaptic proteins such as PSD-95 and AMPA-type glutamate receptor subunits (Waters et al., 2009), long-term potentiation (LTP; Ogiue-Ikeda et al., 2008), long-term depression (LTD; Mukai et al., 2007), intracellular $\mathrm{Ca}^{2+}$ dynamics (Zhao and Brinton, 2007), and activation of the extracellular signal-regulated kinase (ERK)-mitogen-activated pro-

\footnotetext{
Received April 23, 2013; revised July 22, 2013; accepted Aug. 10, 2013.

Author contributions: M.I.B. and K.M.F. designed research; M.I.B. and J.D.H. performed research; M.I.B. analyzed data; M.I.B. and K.M.F. wrote the paper.

This work was supported by a University of Wisconsin-Milwaukee Research Growth Initiative Award to K.M.F. and by the University of Wisconsin-Milwaukee. We thank Jaekyoon Kim for assistance with surgeries; and Jennifer Tuscher and Dr. Ashley Fortress for critical comments on this manuscript.

Correspondence should be addressed to Dr. Karyn M. Frick, Department of Psychology, University of WisconsinMilwaukee, 2441 E. Hartford Avenue, Milwaukee, WI 53211. E-mail: frickk@uwm.edu.

DOI:10.1523/JNEUROSCI.1716-13.2013

Copyright $\odot 2013$ the authors $\quad 0270-6474 / 13 / 3315184-11 \$ 15.00 / 0$
}

tein kinase (MAPK) signaling pathway (Boulware et al., 2005; Zhao and Brinton, 2007).

Classical effects of $E_{2}$ occur within a time course of hours to days and are characterized by intracellular ERs binding to estrogen response elements in the promoter regions of DNA, leading to increased transcription of target genes. More recently, alternative nonclassical mechanisms of $\mathrm{E}_{2}$ action have been shown to occur within seconds to minutes, and are triggered by membrane receptor-initiated activation of multiple intracellular signaling cascades, which increase gene expression via epigenetic alterations and activation of transcription factors such as CREB (Gu and Moss, 1996; Wade and Dorsa, 2003; Boulware et al., 2005; Szego et al., 2006; Zhao et al., 2010, 2012). One emerging model of rapid nonclassical $E_{2}$ action involves the activation of G-protein-coupled receptors (GPCRs) by membrane-localized ERs (Meitzen and Mermelstein, 2011). In hippocampal pyramidal and striatal mediumspiny neurons, activation of membrane-localized ERs induces group I and group II metabotropic glutamate receptor (mGluR) signaling, leading to bidirectional regulation of CREB phosphorylation (Boulware et al., 2005; Grove-Strawser et al., 2010). ERmGluR interactions have also been implicated in the rapid actions of $\mathrm{E}_{2}$ on dorsal root ganglion excitation (Chaban et al., 2011), neuroprogesterone synthesis (Kuo et al., 2010), and lordosis (Dewing et al., 2007). Although hippocampal ER/mGluR signaling has been demonstrated in vitro (Boulware et al., 2005), 
it is unknown whether these receptor interactions occur in vivo to mediate the effects of $\mathrm{E}_{2}$ on hippocampal memory.

The present study used hippocampal-dependent novel object recognition (NOR) and object placement (OP) tasks, in conjunction with in vivo pharmacological manipulation, to pinpoint the roles of $\mathrm{ER} \alpha, \mathrm{ER} \beta$, and mGluR1a in mediating the effects of $\mathrm{E}_{2}$ on hippocampal memory consolidation. We demonstrated previously that infusion of $\mathrm{E}_{2}$ (or a membrane-impermeable analog of $\mathrm{E}_{2}$ ) into the dorsal hippocampus $(\mathrm{DH})$ of young ovariectomized female mice immediately after novel object recognition training enhances memory consolidation in an ERK-dependent manner (Fernandez et al., 2008; Zhao et al., 2010, 2012). E 2 treatment also enhances object placement memory, a hippocampal-dependent form of spatial memory (Luine et al., 2003; Walf et al., 2008). Here, we report that post-training DH infusion of an ER $\alpha$ or ER $\beta$ agonist enhances novel object recognition and spatial memory consolidation, and that these effects are dependent on DH p42 ERK activation. Further, we found that DH infusion of an mGluRla antagonist blocks ER-mediated ERK activation and memory enhancement, in agreement with in vitro evidence that ERs signal through mGluRs in hippocampal neurons (Boulware et al., 2005). Collectively, these data provide the first evidence that rapid ER/mGluR signaling within the $\mathrm{DH}$ is essential for $\mathrm{E}_{2}$ to enhance hippocampal memory.

\section{Materials and Methods}

Subjects. Female C57BL/6 mice ( $8-12$ weeks of age) were purchased from Taconic and housed singly in a room $\left(22-23^{\circ} \mathrm{C}\right)$ with a $12 \mathrm{~h} \mathrm{light/dark}$ cycle. Food and water were provided ad libitum. All behavioral testing was conducted from 8:00 A.M. to 5:00 P.M. in a quiet room. All procedures were approved by the University of Wisconsin-Milwaukee Animal Care and Use Committee, and are in accordance with the National Institutes of Health Guide for the Care and Use of Laboratory Animals.

Surgery. Mice underwent bilateral ovariectomy and guide cannulae implantation in the same surgical session, as described previously (Fernandez et al., 2008; Zhao et al., 2010, 2012). Briefly, mice were anesthetized with isoflurane gas (5\% for induction, $2 \%$ for maintenance, in $100 \%$ oxygen) and placed in a stereotaxic apparatus (Kopf Instruments). They were first ovariectomized and then implanted with stainless steel intracranial guide cannulae (22 gauge; C232GC, Plastics One) with inserted dummy cannulae (C232DC, Plastics One). Guide cannulae were aimed at the DH [intrahippocampal; $-1.7 \mathrm{~mm}$ anteroposterior $(\mathrm{A} / \mathrm{P})$, $\pm 1.5 \mathrm{~mm}$ mediolateral $(\mathrm{M} / \mathrm{L}),-2.3 \mathrm{~mm}$ dorsoventral (D/V); Paxinos and Franklin, 2003]. In studies in which an inhibitor was coinfused with $\mathrm{E}_{2}$ or an ER agonist, mice were implanted with triple guide cannulae targeting the $\mathrm{DH}$ and the dorsal third ventricle (intracerebroventricular; $-0.9 \mathrm{~mm} \mathrm{~A} / \mathrm{P}, \pm 0.0 \mathrm{~mm} \mathrm{M} / \mathrm{L},-2.3 \mathrm{~mm} \mathrm{D} / \mathrm{V})$. We use this triple infusion procedure to prevent tissue damage from repeated infusions into the DH (Fernandez et al., 2008; Fan et al., 2010; Zhao et al., 2010; Fortress et al., 2013). Cannulae were affixed to the skull with dental cement, which also served to close the wound. Mice recovered for 7-10 d before behavioral testing or drug infusion.

Drugs and infusions. During infusions, mice were gently restrained, dummy cannulae were removed, and drugs were infused via internal infusion cannulae (C3131; intrahippocampal: 28 gauge, extending 0.8 $\mathrm{mm}$ beyond the $1.5 \mathrm{~mm}$ guide; intracerebroventricular: 28 gauge, extending $1.0 \mathrm{~mm}$ beyond the $1.8 \mathrm{~mm}$ guide). A microinfusion pump (KDS Legato 180; KD Scientific) was used to control infusions through polyethylene tubing (PE20) connected to a $10 \mu \mathrm{l}$ syringe (Hamilton). Drugs were infused bilaterally into the $\mathrm{DH}$ at a rate of $0.5 \mu \mathrm{l} / 1 \mathrm{~min}$ and unilaterally into the dorsal third ventricle at a rate of $1 \mu \mathrm{l} / 2 \mathrm{~min}$. This infusion protocol results in $\sim 1 \mathrm{~mm}^{3}$ of drug diffusion (Lewis and Gould, 2007). Given the coordinates of the DH infusion, this diffusion radius suggests that effects of drugs infused into the $\mathrm{DH}$ were likely restricted to this area. Although intracerebroventricularly infused $\mathrm{E}_{2}$ or ER agonists may diffuse to other brain regions, we have previously shown that the $\mathrm{DH}$ is essential for the effects of $\mathrm{E}_{2}$ on object memory consolidation (Fernandez et al., 2008; Zhao et al., 2012), and thus the effects of $E_{2}$ in other brain regions appear to be negligible in this paradigm. Injection cannulae were left in place for $1 \mathrm{~min}$ following infusion to assure that drugs did not diffuse up the cannula tract. In experiments using triple cannulae, infusions were first given into the $\mathrm{DH}$, followed immediately by intracerebroventricular infusion. Drug infusions paired with behavioral testing were administered immediately after training.

A rapidly metabolized form of $E_{2}, \beta$-cyclodextrin-encapsulated $E_{2}$ (Sigma-Aldrich), was dissolved in physiological saline to a concentration of $5.0 \mu \mathrm{g} / 0.5 \mu \mathrm{l}$ and infused at a dose of $5 \mu \mathrm{g}$ per hemisphere for $\mathrm{DH}$ infusions and $10 \mu \mathrm{g}$ total for intracerebroventricular infusions (Fernandez et al., 2008; Zhao et al., 2010, 2012). The vehicle, 2-hydroxypropyl$\beta$-cyclodextrin (Sigma-Aldrich), was dissolved in an equal volume of saline and contained the same amount of cyclodextrin as $E_{2}$. The MEK inhibitor U0126 (1,4-diamino-2,3-dicyano-1,4-bis (o-aminophenylmercapto) butadiene; Promega) was dissolved to $0.5 \mu \mathrm{g} / 0.5 \mu \mathrm{l}$ in $50 \%$ dimethylsulfoxide (DMSO) in saline, for a dose of $0.5 \mu \mathrm{g}$ per hemisphere (Fernandez et al., 2008; Zhao et al., 2010, 2012). This dose does not impair novel object recognition (Fernandez et al., 2008) or object placement memory (see Fig. 2A) on its own. The ER $\alpha$ agonist PPT (4,4' $4^{\prime \prime}$-(4-propyl-[ $\left.1 H\right]$-pyrazole-1,3,5-triyl) tris-phenol; Tocris Bioscience) was dissolved in $0.1 \mathrm{pg} / 0.5 \mu \mathrm{l}$ in $0.01 \%$ DMSO in saline and infused at a dose of $0.1 \mathrm{pg}$ per hemisphere. PPT has a 410-fold greater affinity for ER $\alpha$ over ER $\beta$ (Stauffer et al., 2000). The ER $\beta$ agonist DPN (2,3-bis(4-hydroxyphenyl)-propionitrile, Tocris Bioscience) was dissolved to $10 \mathrm{pg} / 0.5 \mu \mathrm{l}$ in $0.1 \%$ DMSO in saline and infused at a dose of 10 pg per hemisphere. DPN has a 70-fold greater affinity for ER $\beta$ over ER $\alpha$ (Meyers et al., 2001). At these very low doses, PPT and DPN are specific for $\mathrm{ER} \alpha$ and $\mathrm{ER} \beta$, respectively (Stauffer et al., 2000). The mGluRla antagonist LY367385 ( $(S)-(+)$ - $\alpha$-Amino-4-carboxy-2-methylbenzeneacetic acid; Tocris Bioscience) was dissolved to $10 \mathrm{pg} / 0.5 \mu \mathrm{l}$ or $1 \mathrm{ng} / 0.5 \mu \mathrm{l}$ in $0.1 \%$ DMSO in saline.

Novel object recognition and object placement. NOR was tested using a hippocampal-dependent novel object recognition task (Clark et al., 2000; Baker and Kim, 2002), conducted as described previously (Frick and Gresack, 2003; Fernandez and Frick, 2004). Spatial memory was tested using an OP task adapted from previously published work (Luine et al., 2003; Li et al., 2004). All drugs were administered immediately posttraining in both tasks to pinpoint specific effects on memory consolidation. Post-training systemic injection or DH infusion of $\mathrm{E}_{2}$ enhances memory consolidation in both tasks (Luine et al., 2003; Fernandez et al., 2008; Walf et al., 2008; Zhao et al., 2010, 2012). Sample sizes for each group are given in the figures representing NOR and OP data.

Before NOR testing, mice were handled briefly $(1 \mathrm{~min} / \mathrm{d})$ for $3 \mathrm{~d}$ and acclimated to objects by placing a small Lego in their home cage on the first day of handling. The Lego remained in the home cage for $5 \mathrm{~d}$ and was removed immediately after NOR training. After the completion of handling, mice were habituated to the empty white testing chamber (width, $60 \mathrm{~cm}$; length, $60 \mathrm{~cm}$; height, $47 \mathrm{~cm}$ ) for $5 \mathrm{~min}$ for $2 \mathrm{~d}$. The following day, mice were rehabituated to the box for 2 min and subsequently removed to the home cage, and then two identical objects were placed near the northwest and northeast corners of the box. Mice were then returned to the box, allowed to accumulate $30 \mathrm{~s}$ exploring the objects (exploration recorded when the front paws or nose contacted the object), and then were immediately removed, infused, and returned to their home cage. After 24 or $48 \mathrm{~h}$, NOR was tested by returning each mouse to the testing chamber and allowing them to explore one object identical to that explored on the training day (familiar object) and one new (novel) object. Mice again accumulated $30 \mathrm{~s}$ exploring the objects. More time than chance (15 s) spent with the novel object indicated memory for the familiar object (Frick and Gresack, 2003). Because vehicle-treated, ovariectomized mice remember the familiar object $24 \mathrm{~h}$, but not $48 \mathrm{~h}$, after training (Gresack et al., 2007), we use the $24 \mathrm{~h}$ time point to test the memory-impairing effects of drugs and the $48 \mathrm{~h}$ time point to test memory-enhancing effects of drugs (Fan et al., 2010; Zhao et al., 2012).

OP training was conducted 9-10 d after NOR. Mice were rehabituated and then trained with two identical objects as in the NOR task. Four or twenty-four hours later, each mouse was returned to the testing chamber 
in which one of the identical objects had been moved to the southwest or southeast corner of the box. Mice were again allowed to accumulate $30 \mathrm{~s}$ exploring the objects. More time than chance (15 s) spent with the moved object indicated memory for the unmoved object. Vehicle-treated mice remember the placement of the unmoved object $4 \mathrm{~h}$, but not $24 \mathrm{~h}$, after training (see Fig. $3 B$ ). Thus, the $4 \mathrm{~h}$ time point was used to identify a dose of the mGluRla antagonist and ERK inhibitor that did not impair OP memory on their own.

Western blotting. We have previously demonstrated that $\mathrm{E}_{2}$ infusion rapidly activates dorsal hippocampal p42 ERK within $5 \mathrm{~min}$, that this activation is downstream of $E_{2}$ induced activation of other kinases (e.g., PI3K and Akt), and that dorsal hippocampal ERK activation is necessary for $\mathrm{E}_{2}$ to enhance NOR and OP memory (Fernandez et al., 2008; Fan et al., 2010; Fig. 1B). As such, ERK phosphorylation was used here as a measure of rapid activation of $\mathrm{DH}$ cell signaling. Two weeks after the conclusion of behavioral testing, mice were again infused and killed 5 min later. The DH was then dissected bilaterally on ice. Western blotting was conducted as described previously (Fernandez et al., 2008; Lewis et al., 2008). Tissue was stored at $-80^{\circ} \mathrm{C}$ until homogenization (probe sonicator, Sonifier 250; Branson) in icecold, hypotonic lysis buffer (1:50 w/v) containing a protease inhibitor cocktail (EDTA-free; Thermo Scientific). After total protein content was measured, proteins were separated on $10 \%$ or $4-20 \%$ Tris- $\mathrm{HCl}$ gels and transferred to PVDF membranes (Bio-Rad). Membranes were then blocked and incubated with primary antibody (phospho-ERK or total-ERK, 1:2000; Cell Signaling Technology) overnight at $4^{\circ} \mathrm{C}$. The following day, membranes were washed, incubated for $1 \mathrm{~h}$ at room temperature with HRP-conjugated goat anti-rabbit IgG (1: 20,000; Cell Signaling Technology), and developed using enhanced chemiluminescence (Pierce). The signal was detected using a GelLogic 6000 PRO imager (Carestream), and densitometry for phosphorylated ERK and total ERK performed using Carestream Molecular Imaging software. Phospho-p42 ERK and phospho-p44 ERK values were normalized to total ERK and expressed as a percentage relative to vehicle controls. Treatment effects were measured within gels. Sample sizes for each group are given in the figures representing Western blot data.

Sucrose density fractionation. Hippocampi from female mice were pooled $(n=7)$ and detergent-resistant membranes (DRMs) isolated as described previously (Kumari and Francesconi, 2011). Briefly, after dissection, tissue was homogenized in ice-cold buffer $(10 \mathrm{~mm}$ Tris- $\mathrm{HCl}, \mathrm{pH}$ 7.4, $5 \mathrm{~mm}$ EDTA, $320 \mathrm{~mm}$ sucrose, and protease inhibitors) using a dounce homogenizer ( $\sim 15$ strokes) followed by centrifugation at 3000 $\mathrm{rpm}$ for $10 \mathrm{~min}$ at $4^{\circ} \mathrm{C}$. The pellet was recovered and resuspended in 1.2 $\mathrm{ml}$ of ice-cold TNEX buffer $(50 \mathrm{~mm}$ Tris- $\mathrm{HCl}, 150 \mathrm{~mm} \mathrm{NaCl}, 5 \mathrm{~mm}$ EDTA, $0.5 \%$ Triton X-100, pH 7.4), sonicated for $5 \mathrm{~s}$ (single pulse, $10 \%$ output amplitude) and incubated on ice for $10 \mathrm{~min}$. After removing a small aliquot for analysis of total protein, the sample was adjusted to $40 \%$ sucrose by the addition of equal parts $80 \%$ sucrose/TNEX. Then, a 5-40\% discontinuous sucrose gradient was formed above the sample and ultracentrifuged (L70; Beckman Instruments) at 39,000 rpm for $16 \mathrm{~h}$ at $4^{\circ} \mathrm{C}$ using a fixed-angle rotor (model T70.1, Beckman Instruments). Samples were collected from the top down and subjected to Western blotting as described above for caveolin-1 (Cav-1), ER $\alpha$, ER $\beta$, Gq, ERK, mGlu1, and transferrin receptor. Primary antibodies used were as follows: $\operatorname{ER} \alpha$ (1:1000; Santa Cruz Biotechnology), ER $\beta$ (1:1000; Thermo
Scientific), Gq (1:1000; Santa Cruz Biotechnology), mGluR1a (1:1000; Cell Signaling Technology), phospho-ERK (1:2000; Cell Signaling Technology), total-ERK (1:2000; Cell Signaling Technology), Cav-1 (1:200; Santa Cruz Biotechnology), and transferrin receptor (1:2000; Abcam). Signal was detected using an HRP-conjugated goat anti-rabbit IgG secondary antibody (1:5000; Cell Signaling Technology).

Coimmunoprecipitation. Dorsal hippocampi from behaviorally tested vehicle-treated mice were dissected bilaterally and homogenized as described above. Coimmunoprecipitation (CoIP) was performed on this whole-cell lysate with the Crosslink Magnetic IP/Co-IP kit (Thermo Scientific) according to instructions provided by the manufacturer. Protein $\mathrm{A} / \mathrm{G}$ magnetic beads were first incubated with either the mGluR1 (5 $\mu \mathrm{g}$; Cell Signaling Technology), ER $\alpha$ ( $5 \mu \mathrm{g}$; Santa Cruz Biotechnology), ER $\beta$ (5 $\mu \mathrm{g}$; Thermo Scientific), Cav-1 (5 $\mu \mathrm{g}$; Cell Signaling Technology), or the normal rabbit negative control antibody $(2 \mu \mathrm{g}$; Cell Signaling Technology), followed by antibody cross-linking with disuccinimidyl suberate to prevent antibody coelution with the antigen. After washing off unbound IP antibody, whole DH proteins $(\sim 650 \mu$ g per reaction $)$ were diluted in $500 \mu \mathrm{l}$ of IP lysis/wash buffer and incubated with the beads on a rotator overnight at $4^{\circ} \mathrm{C}$. Samples were washed three times, followed by sample elution. Input protein and eluates were then prepared for Western blotting as described above. Primary antibodies used were as follows: $\operatorname{ER} \alpha$ (1:1000; Santa Cruz Biotechnology), ER $\beta$ (1:500; Thermo Scientific), mGluR1 (1:500; Cell Signaling Technology), and Cav-1 (1:500; Cell Signaling Technology).

Statistical analyses. Analyses were conducted using GraphPad Prism 5. One-sample $t$ tests were performed on behavioral data to determine whether the time spent with the novel or moved object differed signifi- 
cantly from chance (15 s; Frick and Gresack, 2003). This analysis is used because time spent with the objects is not independent; time spent with one object reduces time spent with the other object. Mice that failed to accumulate $30 \mathrm{~s}$ with the novel or moved objects during their first testing session were excluded from behavioral data analysis ( $n=5$ of 215). Further, mice that prematurely lost cannulae after the completion of behavioral testing were included in behavioral data analysis, but were not assayed for Western blotting $(n=9$ of 215). For ERK Western blots, one-way ANOVA was conducted separately for p42 and p44 ERK isoforms, followed by Newman-Keuls post hoc tests. Significance was determined at $p<0.05$. Data were expressed as the mean \pm SEM.

\section{Results}

Activation of either ER $\alpha$ or ER $\beta$ enhances hippocampal memory consolidation and increases $\mathrm{p} 42 \mathrm{ERK}$ phosphorylation in the dorsal hippocampus

We first used the specific ER agonists PPT $(\mathrm{ER} \alpha)$ and DPN $(\mathrm{ER} \beta)$ to determine whether $\mathrm{DH}$ activation of these receptors mimics the memory-enhancing effects of $\mathrm{E}_{2}$. Immediately after training, mice received bilateral DH infusion of DMSO vehicle (0.1\%), $\mathrm{E}_{2}$ (5 $\mu \mathrm{g}$ per hemisphere), PPT (0.1 pg per hemisphere), or DPN (10 pg per hemisphere). After $48 \mathrm{~h}$, vehicle-treated mice spent no more time than chance $(15 \mathrm{~s})$ with the novel object, demonstrating that they failed to remember the familiar object. In contrast, mice receiving $\mathrm{DH}$ infusion of $\mathrm{E}_{2}\left(t_{(7)}=5.5, p<0.01\right)$, PPT $\left(t_{(7)}=2.7, p<0.01\right)$, or DPN $\left(t_{(7)}=5.3, p<0.05\right)$ spent significantly more time than chance with the novel object (Fig. 1A), suggesting that activation of $\mathrm{ER} \alpha$ or $\mathrm{ER} \beta$ in the DH mimics the beneficial effects of $\mathrm{E}_{2}$ on NOR memory consolidation. Activation of $\mathrm{ER} \alpha$ or $\mathrm{ER} \beta$ also mimicked the beneficial effects of $\mathrm{E}_{2}$ on spatial memory, as suggested by the fact that mice treated with $\mathrm{E}_{2}$ $\left(t_{(5)}=3.3, p<0.05\right)$, PPT, $\left(t_{(8)}=3.6, p<0.01\right)$, or DPN $\left(t_{(8)}=\right.$ $2.7, p<0.05$ ), but not vehicle, spent significantly more time than chance with the moved object $24 \mathrm{~h}$ after training (Fig. 1B). Given that DH-infused $\mathrm{E}_{2}$ induces p42 ERK, but not p44 ERK, phosphorylation within $5 \mathrm{~min}$ of infusion (Fernandez et al., 2008; Zhao et al., 2010, 2012), we next measured the effects of PPT and DPN on ERK activation. As with $\mathrm{E}_{2}, \mathrm{PPT}$ and DPN significantly increased DH p42 ERK phosphorylation 5 min after infusion $\left(F_{(2,24)}=5.0, p<0.05\right.$; Fig. 1C). Neither treatment affected $\mathrm{p} 44$ ERK phosphorylation (Fig. 1C). Together, these results suggest that $\mathrm{DH}$ activation of either $\mathrm{ER} \alpha$ or $\mathrm{ER} \beta$ is sufficient to enhance both object recognition and spatial memory, possibly via rapid activation of DH p42 ERK signaling.

\section{$E R \alpha$-and ER $\beta$-mediated enhancements in hippocampal memory consolidation require dorsal hippocampal ERK activation}

Because we have previously shown that $\mathrm{E}_{2}$-induced enhancements in NOR memory are dependent on DH p42 ERK phosphorylation (Fernandez et al., 2008), we next examined whether the ER $\alpha$ - and ER $\beta$-dependent modulation of NOR and OP memory also require ERK activation. As in our previous work (Fernandez et al., 2008; Zhao et al., 2010, 2012), mice received bilateral DH infusion of the MEK inhibitor U0126 (0.5 $\mu \mathrm{g}$ per hemisphere) immediately before intracerebroventricular infusion of $\mathrm{E}_{2}, \mathrm{PPT}$, or DPN. We previously showed that DH infusion of this dose of U0126 immediately before intracerebroventricular $\mathrm{E}_{2}$ infusion blocks NOR memory consolidation (Fernandez et al., 2008; Fan et al., 2010), but does not impair NOR memory on its own at a shorter 24 h delay (Fernandez et al., 2008; Fan et al., 2010). Here, we first showed that this dose of U0126 does not impair $4 \mathrm{~h}$ OP memory on its own. Mice received bilateral DH infusion of vehicle (50\% DMSO) or U0126 (0.5 $\mu \mathrm{g}$ per hemi- sphere) immediately following OP training. Four hours later, both vehicle $\left(t_{(5)}=10.6, p<0.01\right)$ and U0126-treated $\left(t_{(5)}=4.8\right.$, $p<0.01)$ mice spent significantly more time than chance with the moved object, suggesting that this dose of U0126 does not affect spatial memory on its own (Fig. $2 A$ ). Next, mice received bilateral DH infusion of vehicle or U0126 followed by intracerebroventricular infusion of vehicle (0.1\% DMSO), PPT (0.2 pg), or DPN $(20 \mathrm{pg})$ immediately after NOR or OP training. Intracerebroventricular infusion of either PPT or DPN enhanced both $48 \mathrm{~h} \mathrm{NOR}$ $t_{(6)}=4.6$ and 4.0 , respectively, $\left.p<0.01\right)$ and $24 \mathrm{~h} \mathrm{OP}\left(t_{(6)}=4.5\right.$ and 5.0, respectively, $p<0.01)$ memory consolidation. U0126 blocked the memory-enhancing effects of PPT and DPN $48 \mathrm{~h}$ after NOR training (Fig. $2 B$ ) and $24 \mathrm{~h}$ after OP training (Fig. 2D), suggesting that ERK activation is necessary for $\mathrm{E}_{2}, \mathrm{ER} \alpha$, and $\mathrm{ER} \beta$ to enhance object recognition and spatial memory consolidation. Finally, to determine whether U0216 could prevent PPT and DPN from increasing p42 ERK phosphorylation in the DH, mice were infused again 9-10 d after OP testing, and the $\mathrm{DH}$ was dissected 5 min later. PPT and DPN significantly increased DH ERK phosphorylation $\left(F_{(5,30)}=5.7, p<0.05\right)$, and these effects were abolished by treatment with U0126 (Fig. 2C). Phosphorylation of p44 ERK was not affected by PPT, DPN, or U0126 (Fig. $2 C$ ). Collectively, these data suggest that p42 ERK signaling is required for the memory-enhancing effects of $\operatorname{ER} \alpha$ and $\operatorname{ER} \beta$ activation in the $\mathrm{DH}$.

mGluR1a signaling regulates both hippocampal memory and the $E_{2}$-induced enhancement of hippocampal memory

In cultured hippocampal neurons, $\mathrm{E}_{2}$ rapidly activates mGluR1a signaling and downstream activation of ERK (Boulware et al., 2005). As such, we next tested whether inhibition of DH mGluRla activation could block the mnemonic effects of $\mathrm{E}_{2}$ in vivo. Because mGluRs are involved in mediating hippocampal memory (for review, see Lüscher and Huber, 2010), we first needed to demonstrate that the effects of mGluRla inhibition on $\mathrm{E}_{2}$-induced memory consolidation are not the result of general memory blockade by LY367385. We, therefore, needed to find a dose of LY367385 that did not block memory consolidation on its own. To this end, we infused mice with one of two doses of LY367386 (10 pg per hemisphere or 1 ng per hemisphere) immediately after training in the NOR and OP tasks, and tested memory 24 and $4 \mathrm{~h}$ later, respectively. Mice receiving vehicle $\left(t_{(7)}=\right.$ $4.5, p<0.005)$ or $10 \mathrm{pg}$ of LY367385 $\left(t_{(8)}=2.8, p<0.05\right)$ spent significantly more time than chance $(15 \mathrm{~s})$ with the novel object $24 \mathrm{~h}$ after NOR training (Fig. $3 \mathrm{~A}$ ), whereas mice receiving $1 \mathrm{ng}$ of LY367385 did not, indicating that the $10 \mathrm{pg}$ per hemisphere dose did not prevent memory consolidation on its own. Similarly, mice receiving both vehicle $\left(t_{(6)}=2.9, p<0.05\right)$ and $10 \mathrm{pg}$ of LY367385 $\left(t_{(7)}=4.2, p<0.005\right)$ spent significantly more time than chance with the moved object $4 \mathrm{~h}$ after OP training (Fig. $3 B$ ), whereas mice receiving $1 \mathrm{ng}$ of LY367385 did not. Together, these data suggest that mGluR1a activation is critical for NOR and OP memory consolidation and that the behaviorally ineffective $10 \mathrm{pg}$ dose of LY367385 is appropriate for subsequent use with $E_{2}$.

Next, a new set of mice received bilateral DH infusions of vehicle (0.1\% DMSO) or LY367385 (10 pg per hemisphere) and intracerebroventricular infusion of vehicle (2-hydroxypropylbeta-cyclodextrin) or $\mathrm{E}_{2}(10 \mu \mathrm{g})$ immediately after NOR and OP training. Memory was tested 48 and $24 \mathrm{~h}$ later, respectively. In both tasks, LY367385 blocked the memory-enhancing effects of $\mathrm{E}_{2}$ (Fig. $3 C, D$ ). For both tasks, only mice infused with $\mathrm{E}_{2}$ plus vehicle showed a preference for the novel object $\left(t_{(8)}=4.5, p<\right.$ 0.005 ; Fig. $3 C)$ and moved object $\left(t_{(9)}=6.6, p<0.001\right.$; Fig. $\left.3 D\right)$. 

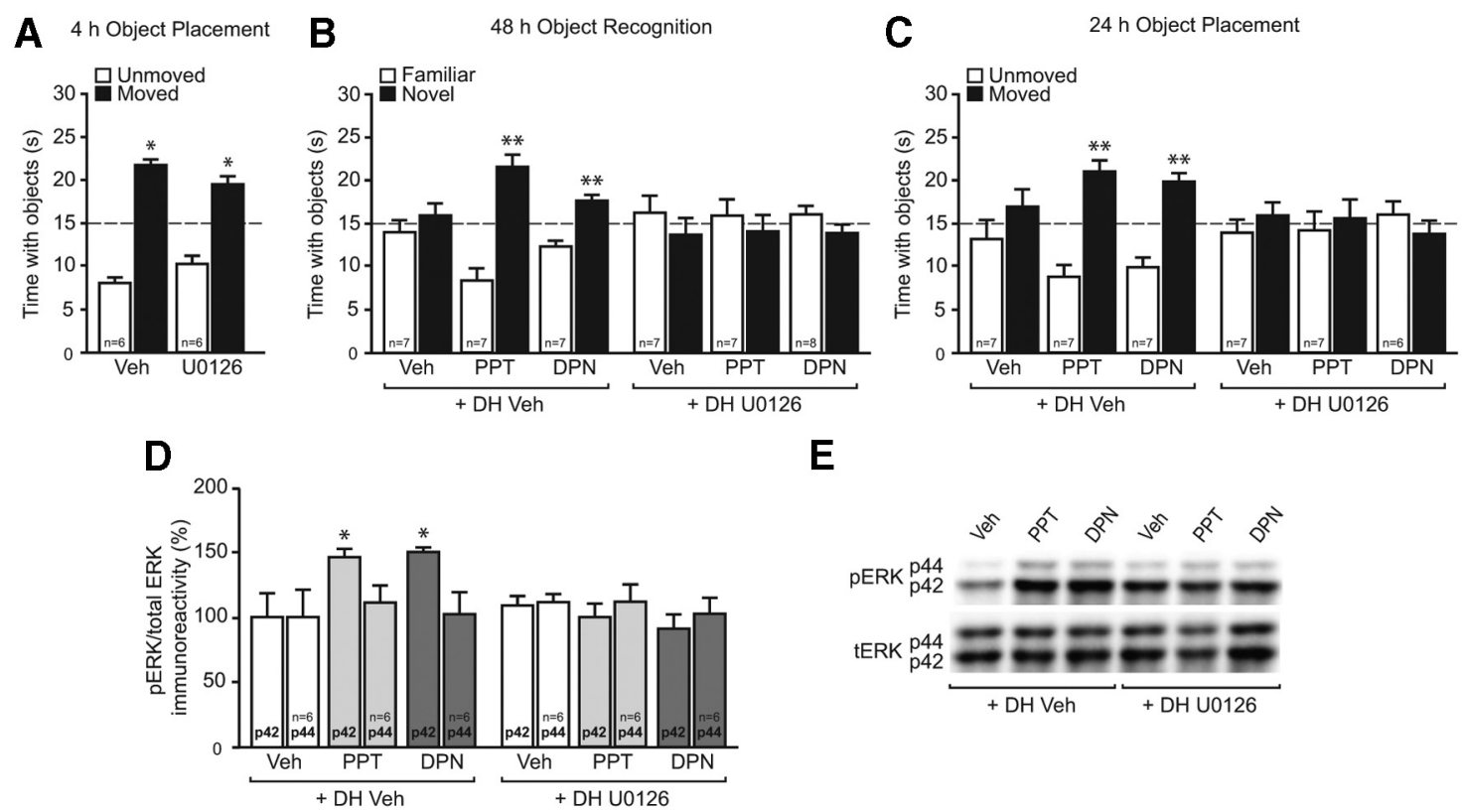

E

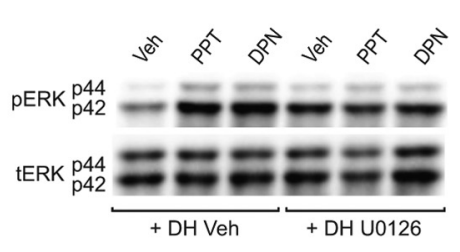

Figure 2. DH ERK signaling is necessary for ER $\alpha$ - and ER $\beta$-induced NOR and OP memory. A, Mice received DH infusion of $50 \%$ DMSO vehicle (Veh) or the MEK inhibitor U0126 (0.5 $\mu g$ per side) immediately after $\mathrm{OP}$ training and were tested $4 \mathrm{~h}$ later. Both vehicle- and U0126-treated mice spent significantly more time with the moved object than chance (dashed line at $15 \mathrm{~s}$; ${ }^{*} p<0.05$ ), indicating that this dose of U0126 does not impair spatial memory on its own. $B, C$, Immediately after NOR and OP training, mice received DH infusion of DMSO vehicle or U0126, followed by an intracerebroventricular infusion of $0.1 \%$ DMSO vehicle, PPT $(0.2 \mathrm{pg})$, or DPN (20 pg). Mice receiving PPT or DPN plus vehicle spent significantly more time with the novel object (B) and moved object (C) than chance (dashed line at $15 \mathrm{~s} ;{ }^{* *} p<0.01$ ); these effects were blocked by U0126. Bars represent the mean \pm SEM time spent with each object. D, Mice received DH infusion of Veh or U0126 and intracerebroventricular infusion of Veh, PPT, or DPN as above. PPT and DPN significantly increased DH phospho-p42 ERK levels 5 min later ( ${ }^{*} p<0.05$ ); this effect was completely abolished by U0126. $E$, Representative Western blot images illustrating phospho- and total ERK protein levels for each group. Bars represent the mean \pm SEM percentage change from vehicle (100\%).

These results indicate that $\mathrm{E}_{2}$-induced enhancements in object recognition and spatial memory depend on DH mGluR1a activation.

Finally, we investigated whether mGluRla antagonism could also block $\mathrm{E}_{2}$-induced phosphorylation of DH p42 ERK. Treatment significantly affected ERK phosphorylation $\left(F_{(3,32)}=7.9\right.$, $p<0.01)$, such that the $\mathrm{E}_{2}$-induced increase in phospho-p42 ERK levels was blocked by LY367385 $(p<0.01$ relative to all other groups; Fig. 3E). Levels of phospho-p44 ERK in the DH did not differ among the groups (Fig. $3 E$ ). Collectively, these data suggest an important role for mGluRla activation in rapid $\mathrm{E}_{2}$-induced DH p42 ERK activation and subsequent hippocampal memory consolidation.

\section{mGluR1a activation is essential for $\operatorname{ER} \alpha$ and $\operatorname{ER} \beta$ to enhance} hippocampal memory consolidation

We next determined whether mGluRla signaling is required for $\mathrm{ER} \alpha$ and $\operatorname{ER} \beta$ to enhance memory consolidation and p 42 ERK phosphorylation. Immediately after training, mice received bilateral infusions in the DH of vehicle or LY367385 followed by intracerebroventricular infusion of vehicle, PPT, or DPN. NOR and $\mathrm{OP}$ were tested 48 and $24 \mathrm{~h}$ later, respectively, as above. As in Figure 2, PPT and DPN enhanced $\operatorname{NOR}\left(t_{(6)}=7.7, p<0.01\right.$; $t_{(7)}=5.3, p<0.01$, respectively) and OP memory $\left(t_{(6)}=4.7, p<\right.$ $0.01 ; t_{(7)}=3.6, p<0.01$, respectively). In both tasks, LY367385 blocked the memory-enhancing effects of PPT and DPN (Fig. $4 A, B)$. Similarly, LY367385 abolished the increase in DH levels of phospho-p42 ERK induced by PPT and DPN $\left(F_{(5,30)}=5.5, p<\right.$ 0.05; Fig. 4C). Phospho-p44 ERK was not affected by any treatment. Together, these data suggest that mGluRla activation is important for the $\mathrm{ER} \alpha$ - and $\mathrm{ER} \beta$-induced enhancements in both memory consolidation and DH p42 ERK phosphorylation.
ERs, mGluR1, and related signaling molecules are present in detergent-resistant membrane fractions of the mouse hippocampus

Given the importance of ER/mGluRla signaling to memory enhancement, we next determined whether ERs, mGluR1, and related signaling molecules are present within membrane microdomains of the DH. To this end, we dissected and pooled 7-10 female mouse hippocampi and subjected them to detergent-based lysis for sucrose density-gradient ultracentrifugation. Samples were collected from the top down (Fig. $5 A$ ) and were subjected to Western blotting for Cav-1 (a marker of caveolae and lipid rafts), $\mathrm{ER} \alpha, \mathrm{ER} \beta, \mathrm{Gq}, \mathrm{mGluR} 1$, ERK, and transferrin receptor 1 (TfR; negative marker of caveolae/lipid rafts to ensure proper separation; Kumari and Francesconi, 2011). Samples labeled 3, 4, and 5 contained proteins located within DRMs, which include the specialized signaling microdomains, caveolae, and lipid rafts. We observed chemiluminescent detection of all proteins in the total lysate (lane T; Fig. 5B) and heavier fractions (lanes 6-8) upon a 1-2 min exposure. Additionally, we noticed light bands for Cav-1, Gq, and mGluR1 in the DRM fractions (lanes 3-5). To better examine these samples, we ran the DRM fractions separately (lanes 3-5; Fig. 5C) and probed for the same proteins. With increased exposure times (5-15 $\mathrm{min}$ ), we were able to visualize bands for all proteins, except for TfR, within hippocampal DRMs. Note that both $\operatorname{ER} \alpha$ and $\operatorname{ER} \beta$ were present, albeit to a lesser extent than in other cellular compartments, in hippocampal DRMs. As such, the localization of ERs, mGluRs, and ERK within DRMs suggest that membrane-localized classical ERs may signal through mGluRs to initiate the intracellular signaling underlying the beneficial effects of $\mathrm{E}_{2}$ on hippocampal memory consolidation. 
A $24 \mathrm{~h}$ Object Recognition

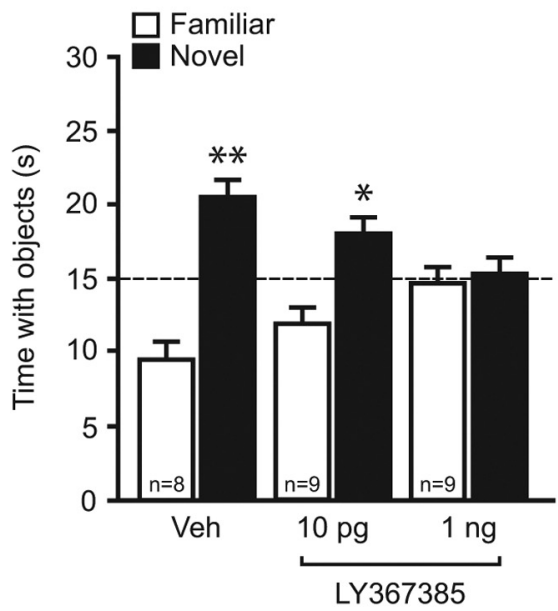

C

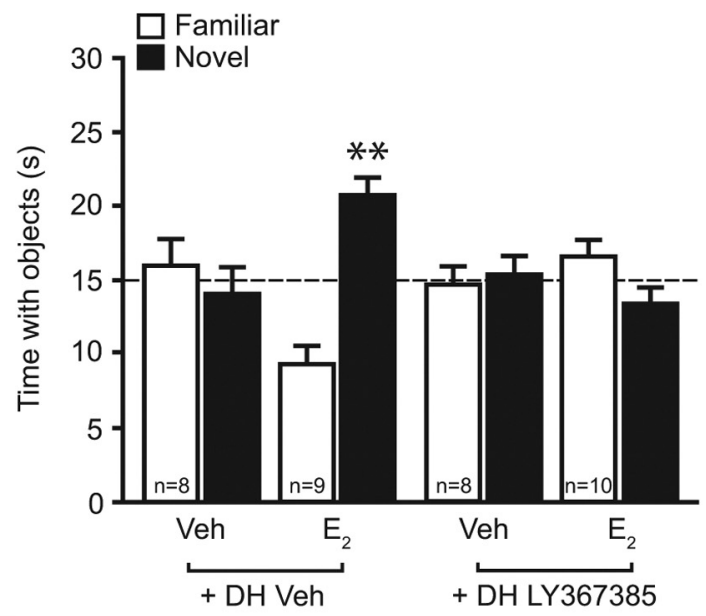

E

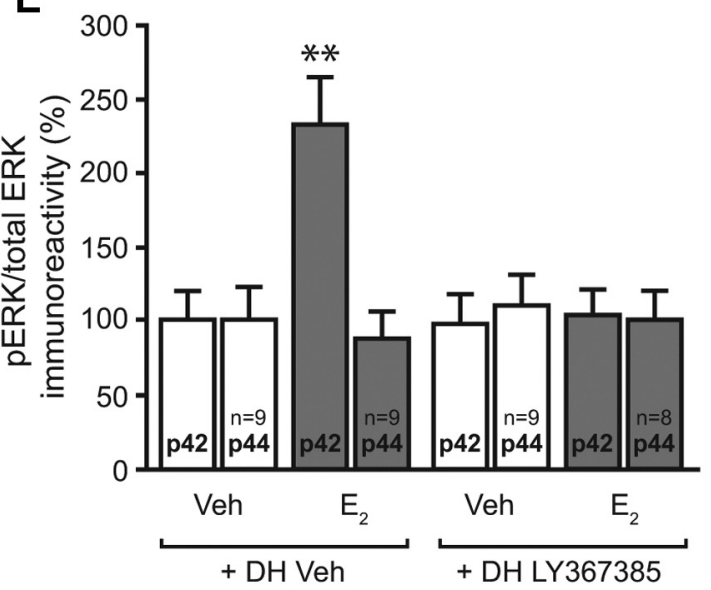

B $\quad 4 \mathrm{~h}$ Object Placement

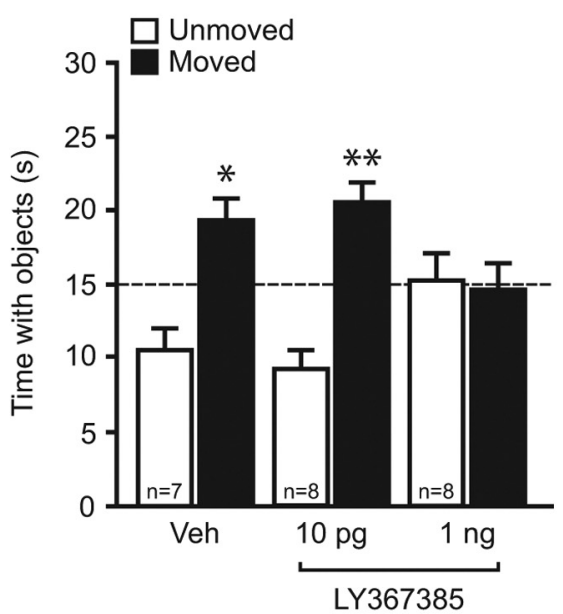

D $24 \mathrm{~h}$ Object Placement
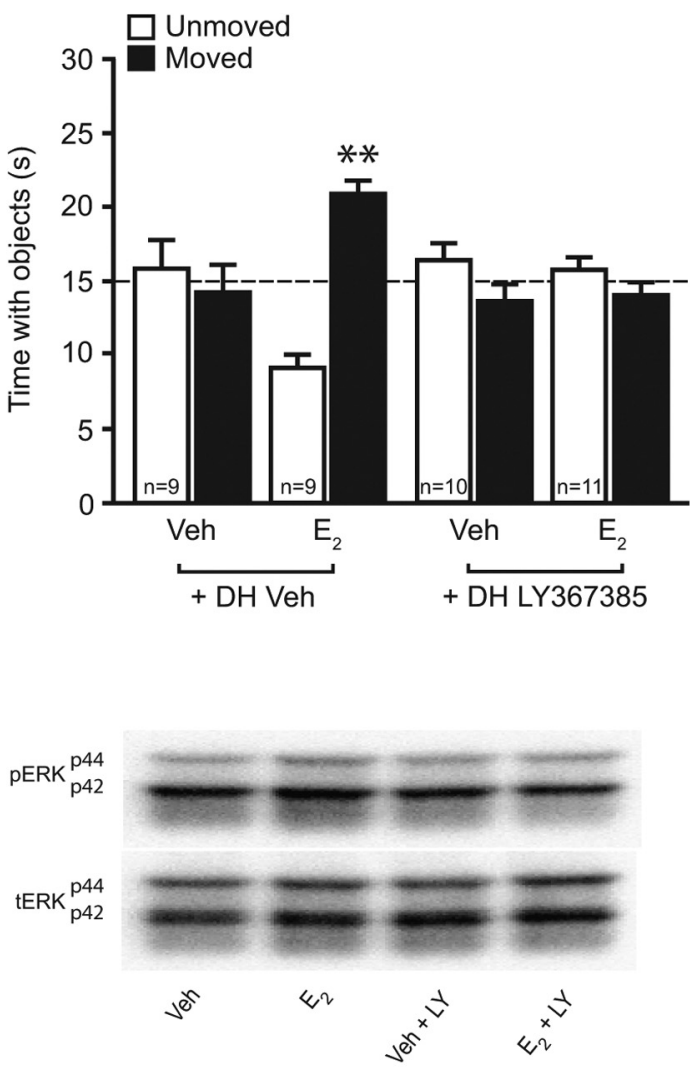

Figure 3. mGluR1a signaling is necessary for $\mathrm{E}_{2}$ to enhance NOR and OP memory, and to rapidly activate DH $\mathrm{p} 42 \mathrm{ERK} . \boldsymbol{A}, \boldsymbol{B}, \mathrm{Immediately}$ after NOR $(\boldsymbol{A})$ and $0 \mathrm{P}(\boldsymbol{B})$ training, mice received DH infusion of $0.1 \%$ DMSO vehicle (Veh) or the mGluR1a antagonist LY367385 (10 pg or $1 \mathrm{ng} / \mathrm{side}$ ). After $24 \mathrm{~h}$, mice treated with vehicle or $10 \mathrm{pg}$ per side LY367385 spent significantly more time with the novel object than chance (dashed line at $15 \mathrm{~s} ;{ }^{*} p<0.05 ;{ }^{* *} p<0.01$ ), indicating memory for the familiar object. Mice receiving 1 ng per side LY367385 spent no more time than chance with the novel object, indicating that this dose impaired NOR memory. Four hours after OP training, mice treated with vehicle or 10 pg per side LY367385 spent significantly more time with the moved object relative to chance $\left({ }^{*} p<0.05 ;{ }^{* *} p<0.01\right)$, indicating preserved memory of the unmoved object. Mice receiving $1 \mathrm{ng}$ per side LY367385 spent no more time than chance with the moved object, indicating that this dose impaired OP memory. $\boldsymbol{C}, \boldsymbol{D}$, Immediately after NOR $(\boldsymbol{C})$ and OP $(\boldsymbol{D})$ training, mice received DH infusion of vehicle or $10 \mathrm{pg}$ per side LY367385, followed by intracerebroventricular infusion of vehicle or $\mathrm{E}_{2}(10 \mu \mathrm{g})$. Mice receiving $\mathrm{E}_{2}$ plus vehicle spent significantly more time with the novel object $(\boldsymbol{C})$ and moved object $(\boldsymbol{D})$ than chance (dashed line at $15 \mathrm{~s}$, $\left.{ }^{* *} p<0.01\right)$, and these effects were blocked by LY367385. Bars represent the mean \pm SEM time spent with each object. $\boldsymbol{E}$, Five minutes after infusion, $\mathrm{E}_{2}$ significantly increased phospho-p42 ERK levels ( ${ }^{* *} p<0.01$ relative to vehicle); this effect was completely blocked by DH LY367385 infusion. Bars represent the mean \pm SEM percentage change from vehicle (100\%). 
A 48 h Object Recognition
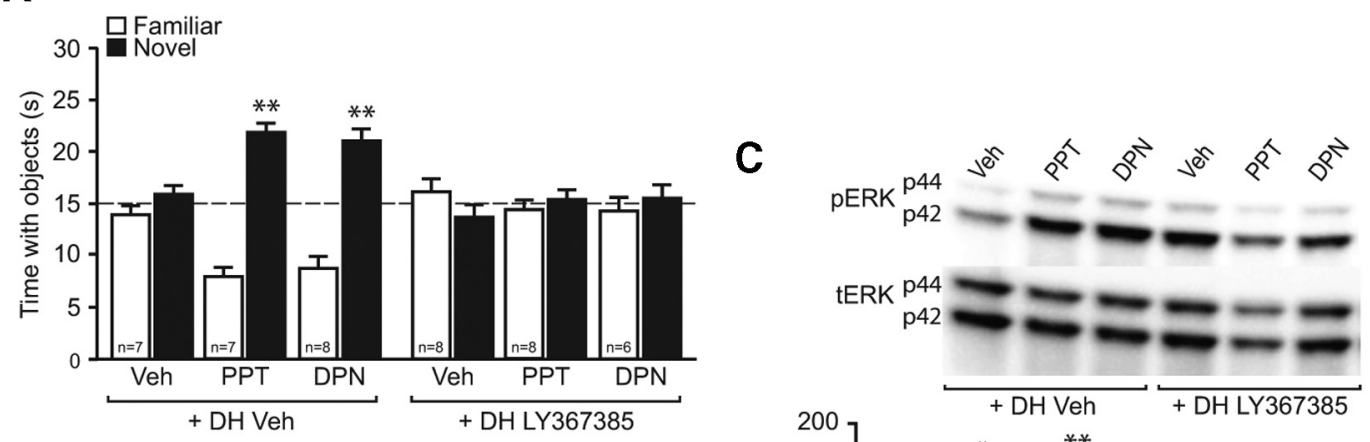

B

24 h Object Placement
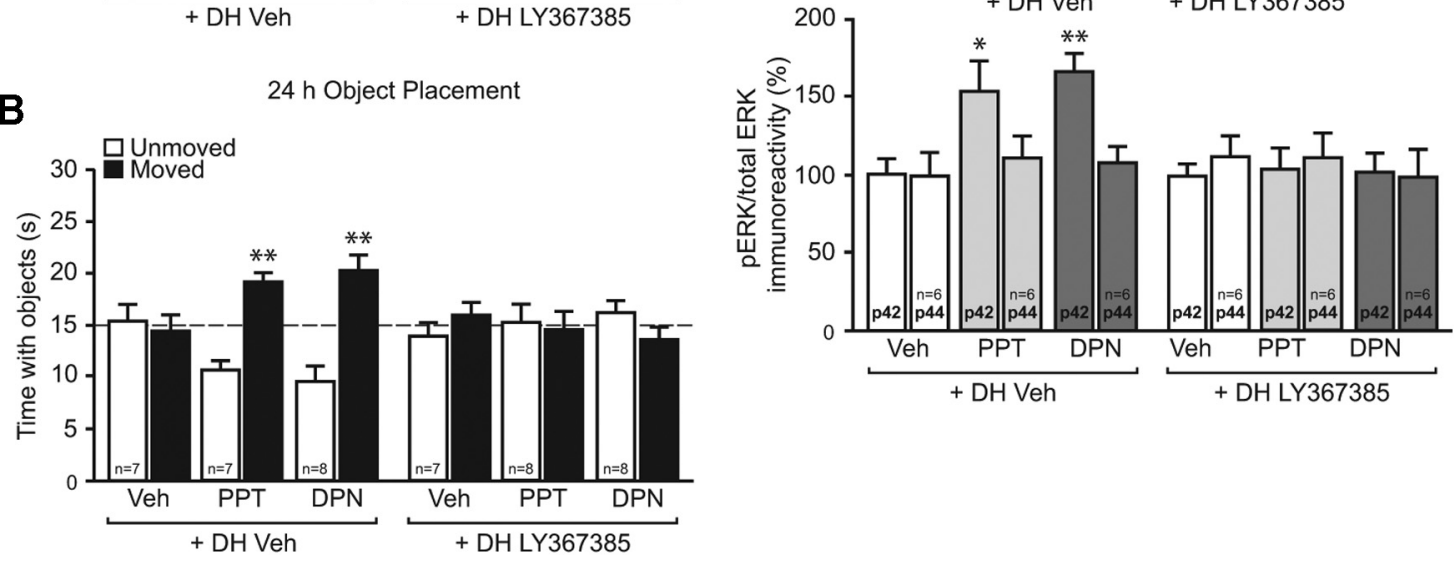

Figure 4. DH mGluR1a signaling is necessary for $E R \alpha$ - and ER $\beta$-induced NOR and OP memory, and DH ERK activation. $A, B$, Immediately after NOR $(\boldsymbol{A})$ and $O P(B)$ training, mice received DH infusion of $0.1 \%$ DMSO vehicle (Veh) or LY367385 (10 pg per side), followed by intracerebroventricular infusion of $0.1 \%$ DMSO vehicle, PPT (0.2 pg), or DPN (20 pg). PPT and DPN significantly increased the time spent with the novel object $(\boldsymbol{A})$ and moved object $(\boldsymbol{B})$ than chance (dashed line at $15 \mathrm{~s},{ }^{* *} p<0.01$ ); these effects were blocked by LY367385. Bars represent the mean \pm SEM time spent with each object. C, Five minutes after infusion, PPT and DPN significantly increased phospho-p42 ERK levels $\left({ }^{*} p<0.05 ;{ }^{* *} p<0.01\right)$; this effect was completely abolished by DH LY367385 infusion. Bars represent the mean \pm SEM percentage change from vehicle (100\%).

ERs, mGluR1, and Cav-1 physically interact in the dorsal hippocampus Given the localization of ERs, mGluR1, Cav-1, and ERK in hippocampal plasma membrane fractions, we next conducted CoIP experiments to determine whether these proteins physically interact. We first tried to examine these interactions in plasma membrane fractions of the $\mathrm{DH}$ but were unable to do so because protein yield from these fractions was too low for use in CoIP reactions. Therefore, the CoIPs were conducted in whole-cell lysates from the DH. As shown in Figure 6, mGluR1 coimmunoprecipitated with $\mathrm{ER} \alpha$ (Fig. 6A), ER $\beta$ (Fig. 6B), and Cav-1 (Fig. $6 D$ ), but not with the negative control normal rabbit IgG. Cav-1, a protein demonstrated to be crucial to ER/mGluR1a receptor signaling in vitro, also coimmunoprecipitated with $\mathrm{ER} \alpha$ (Fig. 6A), $\mathrm{ER} \beta$ (Fig. $6 B$ ), and mGluR1 (Fig. 6C). Finally, the reversal CoIP reactions demonstrated that $\operatorname{ER} \alpha$ and $\operatorname{ER} \beta$ coimmunoprecipitated with mGluR1 (Fig. 6C) and Cav-1 (Fig. 6D). Together, these results support a potential physical interaction between ERs and mGluR1 (possibly via Cav-1) that may underlie the ability of membrane-localized ERs to activate mGluR1a signaling in vivo.

\section{Discussion}

The present findings provide several novel insights into the receptor mechanisms through which $\mathrm{E}_{2}$ enhances hippocampal
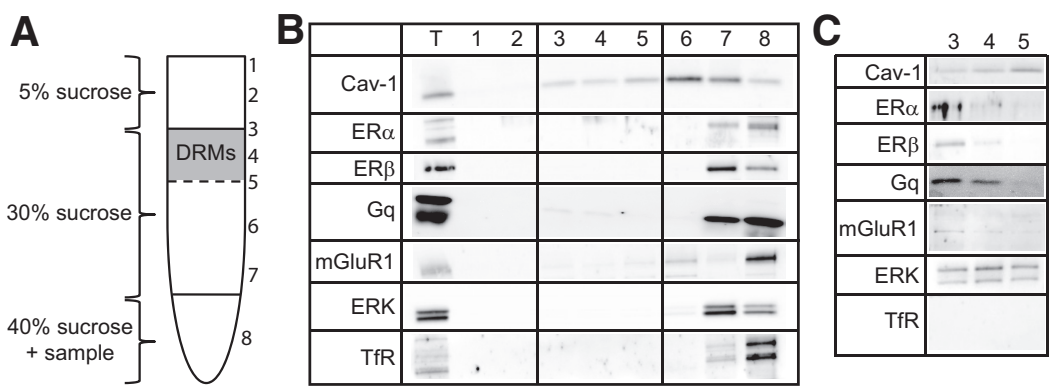

Figure 5. ERs and $\mathrm{E}_{2}$-sensitive signaling molecules are present in DRMs of the hippocampus. $A$, Depiction of the sucrose gradient used to fractionate hippocampal homogenates. DRMs formed a distinct band at the 5-30\% sucrose interface. Samples were collected from the top down, and were subjected to Western blotting for $\mathrm{Cav}-1, \mathrm{ER} \alpha, \mathrm{ER} \beta, \mathrm{ERK}$, mGluR1, and TfR (negative control for DRMs). $\boldsymbol{B}$, Western blots of $20 \mu \mathrm{g}$ for each sample plus total lysate ( $\mathrm{T}$ ). With 1-2 min exposure, protein was observed in some fractions (T, 7, and 8), and light bands for Cav-1, ERK, and mGluR1 were also observed in DRM fractions. C, Hippocampal DRM fractions ( $20 \mu \mathrm{g}$ ) were run separately and probed as in $\boldsymbol{B}$ with $5-15$ min exposure times. All proteins were visible, except for TfR. memory. First, specific DH activation of $\mathrm{ER} \alpha$ or $\mathrm{ER} \beta$ can enhance hippocampal memory consolidation and ERK activation, indicating that either receptor can mediate the memoryenhancing effects of $E_{2}$ via rapid nonclassical mechanisms. Second, the ability of $\mathrm{E}_{2}$ and ER agonists to enhance hippocampal memory depends on mGluRla activation in the $\mathrm{DH}$, suggesting that interaction between ERs and mGluRla is necessary for $\mathrm{E}_{2}$ and ER agonists to enhance hippocampal memory. Finally, $\mathrm{ER} \alpha, \mathrm{ER} \beta, \mathrm{mGluR} 1, \mathrm{Cav}-1, \mathrm{ERK}$, and Gq proteins are localized within hippocampal detergent-resistant membranes in vivo, and $\operatorname{ER} \alpha$ and $\operatorname{ER} \beta$ coimmunoprecipitate with mGluR1 and Cav-1, suggesting that physical interactions between the 
A
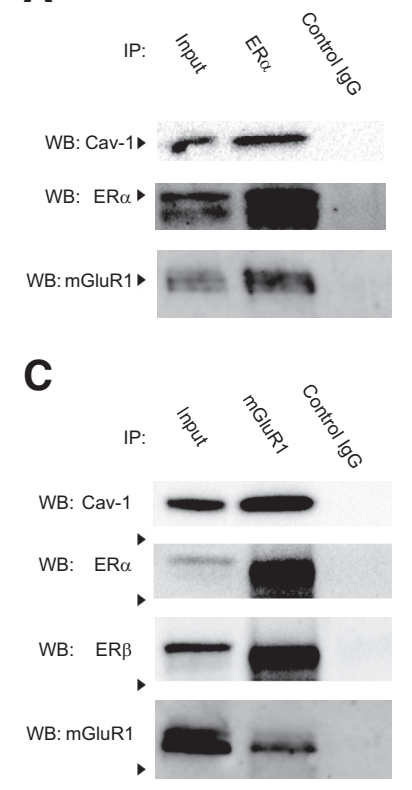

B

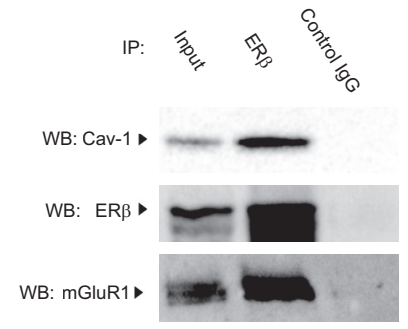

D

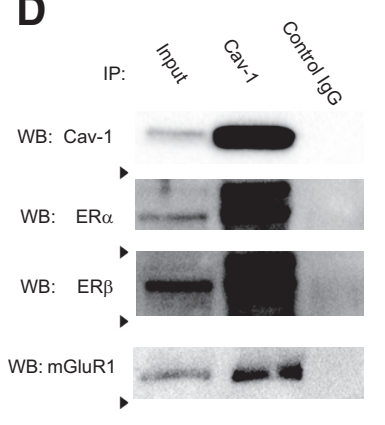

Figure 6. ERs, mGluR1, and Cav-1 coimmunoprecipitate in DH whole-cell lysates. $\boldsymbol{A}-\boldsymbol{D}$, Whole-cell DH lysates were immunoprecipitated using $\operatorname{ER} \alpha(\boldsymbol{A}), \operatorname{ER} \beta(\boldsymbol{B}), \mathrm{mGluR1}(\boldsymbol{C})$, or Cav-1 (D) antibodies, and a negative control normal rabbit antibody (Control lgG; all panels). The lysate was also run as a positive control (Input). Western blots (WBs) were then probed for ERs, mGluR1, and Cav-1. mGluR1 and Cav-1 coimmunoprecipitated with $\operatorname{ER} \alpha(\boldsymbol{A})$ and $\operatorname{ER} \beta(\boldsymbol{B})$. Reversal ColPs demonstrated that $\operatorname{ER} \alpha$ and $\operatorname{ER} \beta$ coimmunoprecipitated with mGluR1 $(C)$ and Cav-1 (D). Finally, mGluR1 and Cav-1 also coimmunoprecipitated in these lysates $(\boldsymbol{C}, \boldsymbol{D})$. Together, these data suggest physical interactions among ERs, mGluR1, and Cav- 1 in the DH.

ERs and integral membrane proteins may promote ER/mGlu receptor signaling.

The ability of $E_{2}$ to rapidly activate the ERK/MAPK signaling pathway has been demonstrated in vitro (Boulware et al., 2005; Zhao and Brinton, 2007) and in vivo (Fernandez et al., 2008; Zhao et al., 2010, 2012). Further, we have shown using DH and intracerebroventricular infusions of $\mathrm{E}_{2}$ and U0126 that DH ERK activation is necessary for $\mathrm{E}_{2}$ to enhance NOR memory consolidation in young female mice (Fernandez et al., 2008; Zhao et al., 2010, 2012). However, the roles of $\operatorname{ER} \alpha$ and $\operatorname{ER} \beta$ in mediating the effects of $\mathrm{E}_{2}$ on ERK signaling and memory have been unclear. In vivo, $\mathrm{ER} \beta$ activation most consistently mimics the beneficial effects of $E_{2}$ on hippocampal memory in female rodents, including NOR and OP memory (Walf et al., 2008; Jacome et al., 2010). $\mathrm{ER} \alpha$ activation typically improves or has no effect on hippocampal memory (Frye et al., 2007; Jacome et al., 2010; Phan et al., 2011). Nevertheless, the specific contributions of hippocampal $\mathrm{ER} \alpha$ and $\operatorname{ER} \beta$ to hippocampal memory consolidation have remained unknown because ER agonists have been administered only systemically thus far. Here, we used targeted infusions of low doses of PPT and DPN to ensure their specificity in terms of localization of action and precise receptor activation (Stauffer et al., 2000). Both PPT and DPN enhanced NOR and OP memory consolidation, indicating that both $\operatorname{ER} \alpha$ and $\operatorname{ER} \beta$ can mediate $\mathrm{E}_{2}$-induced memory consolidation in vivo. This finding is interesting given some reports showing disparate effects of systemic PPT and DPN on NOR and OP in female rodents (Walf et al., 2006; Frye et al., 2007; Frick et al., 2010). Systemic treatments affect tissues throughout the body, so apparent inconsistencies with our intracranial infusions may result from the more specific targeting of $\mathrm{ER} \alpha$ and $\mathrm{ER} \beta$ in the present study. Within the hippocampus, PPT and DPN seem to have comparable effects; for

example, both drugs are neuroprotective and increase p42 ERK phosphorylation in cultured hippocampal neurons (Zhao and Brinton, 2007). Phosphorylation of p42 ERK also appears essential for the mnemonic effects of PPT and DPN, and systemic studies did not measure this activation. Indeed, p42 ERK activation is necessary for $\mathrm{E}_{2}$ to enhance NOR (Fernandez et al., 2008; Zhao et al., 2010, 2012), and the present study found that both PPT and DPN significantly increased p42 ERK phosphorylation within 5 min of $\mathrm{DH}$ infusion. As with $\mathrm{E}_{2}$, the $\mathrm{ER} \alpha$ - and $\mathrm{ER} \beta$ induced enhancements in hippocampal memory consolidation were blocked by the MEK inhibitor U0126, demonstrating that both DH ER $\alpha$ and ER $\beta$ enhance memory in an ERK-dependent manner. Thus, the ability of PPT or DPN to regulate dorsal hippocampal p42 ERK activation may dictate the effects of each drug on memory. The present findings provide the first in vivo evidence that both classical ERs in the DH can enhance hippocampal memory through rapid activation of p42 ERK phosphorylation and suggest that either ER can mediate the effects of $E_{2}$ on hippocampal memory.

How do classical ERs rapidly initiate intracellular signaling if their primary structure is that of a cytoplasmic transcription factor? $\operatorname{ER} \alpha$ and $\operatorname{ER} \beta$ can localize to the neuronal membrane surface (Milner et al., 2001, 2005) and are shuttled to the plasma membrane upon $\mathrm{E}_{2}$ binding (Razandi et al., 2002; Sheldahl et al., 2008). $\mathrm{E}_{2}$ rapidly activates mGluR signaling (Meitzen and Mermelstein, 2011), so the potential interaction between ERs and mGluRs provides a mechanism through which $\mathrm{E}_{2}$ can rapidly activate multiple intracellular signaling cascades. mGluRla is a member of the group I mGluRs, which are Gq-coupled receptors that influence hippocampal learning and memory. Hippocampal group I mGluRs facilitate synaptic plasticity (Bortolotto et al., 2005) and regulate both LTP and LTD in this brain region (Bortolotto et al., 1999; Neyman and Manahan-Vaughan, 2008). Further, antagonism of group I mGluRs in the hippocampus impairs spatial reference memory (Naie and Manahan-Vaughan, 2005) and contextual fear conditioning (Frohardt et al., 1999). Consistent with these reports, we found that immediate post-training infusion of $1 \mathrm{ng}$ per hemisphere of the mGluRla antagonist LY367385 blocked both $24 \mathrm{~h}$ NOR and $4 \mathrm{~h}$ OP memory on its own (Fig. $3 A, B$ ), indicating a role for mGluRla in object recognition and spatial memory consolidation. At a lower dose (10 pg per hemisphere), the mGluR1a antagonist did not affect hippocampal memory consolidation on its own, yet completely blocked $\mathrm{E}_{2}$-induced enhancements in NOR and OP memory consolidation. Together with our finding that LY367385 prevented $E_{2}$ from increasing p42 ERK phosphorylation (Fig. $3 E$ ), these data suggest that mGluR1a activation is necessary for $E_{2}$ to enhance hippocampal memory consolidation and induce ERK signaling. PPT- and DPN-induced facilitation of hippocampal memory consolidation and p42 ERK phosphorylation also required DH mGluRla activation, suggesting that $\mathrm{ER} \alpha$ and $\mathrm{ER} \beta$ in the $\mathrm{DH}$ may signal through this GPCR. This is somewhat surprising, given in vitro data demonstrating that PPT, but not DPN, can activate mGluRla in cultured hippocampal pyramidal neurons from female neonatal rat pups (Boulware et al., 2005). However, many factors could contribute to this discrepancy, including key differences in the functional connectivity of in vivo and in vitro systems, maturity of the tissue (neonatal vs adult), drug dose, and species. The importance of these factors to ER/mGluR signaling should be addressed in future work. Finally, it is interesting to note that ER/mGluR signaling does not occur in cultured hippocampal neurons from male rat pups (Boulware et al., 2005), and so future research should examine how sex differences in 
$\mathrm{ER} / \mathrm{mGluR}$ signaling may influence the memory-enhancing effects of $E_{2}$ in males and females.

Although this is the first demonstration that ER/mGluR signaling contributes to hippocampal-mediated behavior, this finding is consistent with previous in vivo studies demonstrating a role for ER/mGluR signaling in other behaviors. For example, $\mathrm{E}_{2}$-induced lordosis behavior in female rats depends on $\mathrm{ER} \alpha$ induced activation of mGluR1a in the arcuate nucleus (Dewing et al., 2007). mGluR5, the other group I mGluR, is abundantly expressed throughout the rat hippocampus (Romano et al., 1995), can activate ERK signaling (Rong et al., 2003; Mao et al., 2005), and plays a role in hippocampus-dependent spatial learning (Simonyi et al., 2010). Although in vitro studies in hippocampal neurons have not linked ERs and mGluR5 (Boulware et al., 2005), $\mathrm{ER} / \mathrm{mGluR} 5$ signaling regulates CREB activation in cultured striatal neurons (Grove-Strawser et al., 2010). As such, further studies are needed to determine whether hippocampal ER/mGluR signaling occurs solely through mGluR1a, or whether mGluR5 can also associate with ERs to influence hippocampal memory consolidation. Moreover, $\mathrm{E}_{2}$ can activate the inhibitory group II mGluRs (mGluR2/3) in cultured hippocampal (Boulware et al., 2005) and dorsal root ganglion neurons (Chaban et al., 2011). In cultured hippocampal pyramidal neurons, $\mathrm{ER} \alpha$ - and $\mathrm{ER} \beta$ induced activation of mGluR2/3 via Cav-3 inhibits L-type calcium channels and attenuates depolarization-induced CREB phosphorylation (Boulware et al., 2005, 2007). Therefore, ERmediated activation of mGluR2/3/Cav-3 could block $\mathrm{E}_{2}$-induced memory consolidation. As such, future research should examine potential contributions of $\mathrm{ER} / \mathrm{mGluR} 2 / 3$ signaling to $\mathrm{E}_{2}$-induced memory enhancement.

$\operatorname{ER} \alpha$ and $\operatorname{ER} \beta$ are found throughout the hippocampus in nuclei, dendritic spines, and axon terminals of pyramidal neurons and interneurons (Milner et al., 2001, 2005). Here, we demonstrate that $\mathrm{ER} \alpha$ and $\mathrm{ER} \beta$, mGluR1, Cav-1, Gq, and ERK are localized to DRMs in the female mouse hippocampus. DRM fractions include caveolae and lipid rafts, which are specialized plasma membrane microdomains in which synaptic components of various neurotransmitter and neurotrophic factor signaling pathways are organized and associated by proteins known as caveolins (Boscher and Nabi, 2012). Physical interactions between $\mathrm{ER} \alpha$ and Cav-1 are necessary for ER $\alpha$ trafficking to the plasma membrane surface (Razandi et al., 2002), and recent studies have confirmed that caveolins are expressed in brain (Cameron et al., 1997; Galbiati et al., 1998; Ikezu et al., 1998; Mikol et al., 1999) where they influence hippocampal plasticity (Braun and Madison, 2000; Gaudreault et al., 2005). We hypothesize that Cav-1 regulates the localization of ERs, mGluRs, and ERK to specialized membrane microdomains, which facilitates their interactions and allows classical ERs to rapidly influence hippocampal memory. This hypothesis is supported by our CoIP findings demonstrating that $\mathrm{ER} \alpha$ and $\mathrm{ER} \beta$ can physically interact with mGluR1 and Cav-1 within the DH. However, alternative explanations cannot be fully excluded. For example, ER activation could indirectly increase mGluR1 at synapses, thereby increasing the effectiveness of LY367385 and result in an apparent blocking of $\mathrm{E}_{2}$ - or ER agonist-induced memory enhancement. Alternatively, $\mathrm{E}_{2}$, PPT, or DPN could increase presynaptic glutamate release, thereby increasing the sensitivity of mGluR signaling, which could then be blocked by a low dose of LY367385. Such alternatives might be addressed by knocking out or knocking down (e.g., via RNA interference) $\mathrm{ER} \alpha, \mathrm{ER} \beta$, mGluR1, or Cav-1 to disrupt their interactions. However, such experiments present significant challenges in vivo; for example, Cav-1 and mGluR knock-out mice exhibit spatial memory (Gioiosa et al., 2008) and LTP (Aiba et al., 1994) impairments, respectively. These deficits would preclude any observation of how interactions among Cav-1, ERs, and mGluR1 influence memory. Moreover, because our data suggest some redundancy in the roles of $\mathrm{ER} \alpha$ and $\mathrm{ER} \beta$ in regulating hippocampal memory consolidation, $\mathrm{E}_{2}$ is likely to still enhance NOR and OP even if only one receptor is reduced or eliminated, and double ER knock-out or knock-down studies would not reveal a specific role of either receptor. If these challenges could be overcome, then the alternative explanations described above could be more definitively tested in future studies.

Although the present study supports an essential role for rapid $\mathrm{ER} / \mathrm{mGluR} 1 \mathrm{a}$ signaling in the memory-enhancing effects of $\mathrm{E}_{2}$, numerous mechanisms exist through which $\mathrm{E}_{2}$ likely influences memory. $\mathrm{E}_{2}$ modulates hippocampal cholinergic function, dendritic morphology and spinogenesis, and neurogenesis (Pompili et al., 2012), all of which are vital to learning and memory processes. Further $\mathrm{E}_{2}$-sensitive membrane receptors, such as G-protein-coupled estrogen receptor (Revankar et al., 2005) and Gq-coupled membrane estrogen receptor (Lagrange et al., 1997; Qiu et al., 2003, 2006), mediate many rapid effects of $E_{2}$ throughout the CNS. Thus, fully understanding the receptor mechanisms through which $\mathrm{E}_{2}$ enhances learning and memory will require more information about how $\mathrm{E}_{2}$-sensitive receptors and signaling pathways within the hippocampus act in concert to regulate memory.

In conclusion, the present study provides the first evidence that the memory-enhancing effects of hippocampal ER activation involve mGluR signaling. The data suggest that $\mathrm{E}_{2}$-induced hippocampal memory consolidation is regulated by interactions between membrane-localized ERs and mGluR1a, which trigger the activation of downstream ERK signaling. The data also provide support for such $\mathrm{ER} / \mathrm{mGluR}$ signaling as a common mechanism through which $E_{2}$ may influence the function of multiple brain regions, thus impacting a wide array of behaviors. These findings are consistent with a growing body of literature indicating that $\mathrm{ER} / \mathrm{mGluR}$ interactions underlie many of the rapid effects of $\mathrm{E}_{2}$ within the CNS (Micevych and Mermelstein, 2008). As such, targeting of mGluRs or their downstream effectors could lead to novel treatments for diseases and disorders characterized by memory impairments.

\section{References}

Aiba A, Chen C, Herrup K, Rosenmund C, Stevens CF, Tonegawa S (1994) Reduced hippocampal long-term potentiation and context-specific deficit in associative learning in mGluR1 mutant mice. Cell 79:365-375. CrossRef Medline

Baker KB, Kim JJ (2002) Effects of stress and hippocampal NMDA receptor antagonism on recognition memory in rats. Learn Mem 9:58-65. CrossRef Medline

Bortolotto ZA, Fitzjohn SM, Collingridge GL (1999) Roles of metabotropic glutamate receptors in LTP and LTD in the hippocampus. Curr Opin Neurobiol 9:299-304. CrossRef Medline

Bortolotto ZA, Collett VJ, Conquet F, Jia Z, van der Putten H, Collingridge GL (2005) The regulation of hippocampal LTP by the molecular switch, a form of metaplasticity, requires mGlu5 receptors. Neuropharmacology 49 [Suppl 1]:13-25. CrossRef

Boscher C, Nabi I (2012) CAVEOLIN-1: role in cell signaling. In: Caveolins and caveolae (Jasmin J-F, Frank P, Lisanti M, eds), pp 29-50. New York: Springer US.

Boulware MI, Weick JP, Becklund BR, Kuo SP, Groth RD, Mermelstein PG (2005) Estradiol activates group I and II metabotropic glutamate receptor signaling, leading to opposing influences on cAMP response elementbinding protein. J Neurosci 25:5066-5078. CrossRef Medline

Boulware MI, Kordasiewicz H, Mermelstein PG (2007) Caveolin proteins 
are essential for distinct effects of membrane estrogen receptors in neurons. J Neurosci 27:9941-9950. CrossRef Medline

Braun JE, Madison DV (2000) A novel SNAP25-caveolin complex correlates with the onset of persistent synaptic potentiation. J Neurosci 20: 5997-6006. Medline

Cameron PL, Ruffin JW, Bollag R, Rasmussen H, Cameron RS (1997) Identification of caveolin and caveolin-related proteins in the brain. J Neurosci 17:9520-9535. Medline

Chaban V, Li J, McDonald JS, Rapkin A, Micevych P (2011) Estradiol attenuates the adenosine triphosphate-induced increase of intracellular calcium through group II metabotropic glutamate receptors in rat dorsal root ganglion neurons. J Neurosci Res 89:1707-1710. CrossRef Medline

Clark RE, Zola SM, Squire LR (2000) Impaired recognition memory in rats after damage to the hippocampus. J Neurosci 20:8853-8860. Medline

Dewing P, Boulware MI, Sinchak K, Christensen A, Mermelstein PG, Micevych P (2007) Membrane estrogen receptor- $\alpha$ interactions with metabotropic glutamate receptor la modulate female sexual receptivity in rats. J Neurosci 27:9294-9300. CrossRef Medline

Fan L, Zhao Z, Orr PT, Chambers CH, Lewis MC, Frick KM (2010) Estradiol-induced object memory consolidation in middle-aged female mice requires dorsal hippocampal extracellular signal-regulated kinase and phosphatidylinositol 3-kinase activation. J Neurosci 30:4390-4400. CrossRef Medline

Fernandez SM, Frick KM (2004) Chronic oral estrogen affects memory and neurochemistry in middle-aged female mice. Behav Neurosci 118:13401351. CrossRef Medline

Fernandez SM, Lewis MC, Pechenino AS, Harburger LL, Orr PT, Gresack JE, Schafe GE, Frick KM (2008) Estradiol-induced enhancement of object memory consolidation involves hippocampal ERK activation and membrane-bound estrogen receptors. J Neurosci 28:8660-8667. CrossRef Medline

Fortress AM, Fan L, Orr PT, Zhao Z, Frick KM (2013) Estradiol-induced object recognition memory consolidation is dependent on activation of mTOR signaling in the dorsal hippocampus. Learn Mem 20:147-155. CrossRef Medline

Frick KM (2012) Building a better hormone therapy? How understanding the rapid effects of sex steroid hormones could lead to novel therapeutics for age-related memory decline. Behav Neurosci 126:29-53. CrossRef Medline

Frick KM, Gresack JE (2003) Sex differences in the behavioral response to spatial and object novelty in adult C57BL/6 mice. Behav Neurosci 117: 1283-1291. CrossRef Medline

Frick KM, Fernandez SM, Harburger LL (2010) A new approach to understanding the molecular mechanisms through which estrogens affect cognition. Biochim Biophys Acta 1800:1045-1055. CrossRef Medline

Frohardt RJ, Guarraci FA, Young SL (1999) Intrahippocampal infusions of a metabotropic glutamate receptor antagonist block the memory of context-specific but not tone-specific conditioned fear. Behav Neurosci 113:222-227. CrossRef Medline

Frye CA, Duffy CK, Walf AA (2007) Estrogens and progestins enhance spatial learning of intact and ovariectomized rats in the object placement task. Neurobiol Learn Mem 88:208-216. CrossRef Medline

Galbiati F, Volonte D, Gil O, Zanazzi G, Salzer JL, Sargiacomo M, Scherer PE, Engelman JA, Schlegel A, Parenti M, Okamoto T, Lisanti MP (1998) Expression of caveolin-1 and -2 in differentiating PC12 cells and dorsal root ganglion neurons: caveolin-2 is up-regulated in response to cell injury. Proc Natl Acad Sci U S A 95:10257-10262. CrossRef Medline

Gaudreault SB, Blain JF, Gratton JP, Poirier J (2005) A role for caveolin-1 in post-injury reactive neuronal plasticity. J Neurochem 92:831-839. CrossRef Medline

Gioiosa L, Raggi C, Ricceri L, Jasmin JF, Frank PG, Capozza F, Lisanti MP, Alleva E, Sargiacomo M, Laviola G (2008) Altered emotionality, spatial memory and cholinergic function in caveolin-1 knock-out mice. Behav Brain Res 188:255-262. CrossRef Medline

Gresack JE, Kerr KM, Frick KM (2007) Life-long environmental enrichment differentially affects the mnemonic response to estrogen in young, middle-aged, and aged female mice. Neurobiol Learn Mem 88:393-408. CrossRef Medline

Grove-Strawser D, Boulware MI, Mermelstein PG (2010) Membrane estrogen receptors activate the metabotropic glutamate receptors mGluR5 and mGluR3 to bidirectionally regulate CREB phosphorylation in female rat striatal neurons. Neuroscience 170:1045-1055. CrossRef Medline
Gu Q, Moss RL (1996) 17 $\beta$-Estradiol potentiates kainate-induced currents via activation of the cAMP cascade. J Neurosci 16:3620-3629. Medline

Ikezu T, Ueda H, Trapp BD, Nishiyama K, Sha JF, Volonte D, Galbiati F, Byrd AL, Bassell G, Serizawa H, Lane WS, Lisanti MP, Okamoto T (1998) Affinity-purification and characterization of caveolins from the brain: differential expression of caveolin-1, -2, and -3 in brain endothelial and astroglial cell types. Brain Res 804:177-192. CrossRef Medline

Jacome LF, Gautreaux C, Inagaki T, Mohan G, Alves S, Lubbers LS, Luine V (2010) Estradiol and ER $\beta$ agonists enhance recognition memory, and DPN, an ER $\beta$ agonist, alters brain monoamines. Neurobiol Learn Mem 94:488-498. CrossRef Medline

Kumari R, Francesconi A (2011) Identification of GPCR localization in detergent resistant membranes. Methods Mol Biol 746:411-423. CrossRef Medline

Kuo J, Hamid N, Bondar G, Prossnitz ER, Micevych P (2010) Membrane estrogen receptors stimulate intracellular calcium release and progesterone synthesis in hypothalamic astrocytes. J Neurosci 30:12950-12957. CrossRef Medline

Lagrange AH, Ronnekleiv OK, Kelly MJ (1997) Modulation of G proteincoupled receptors by an estrogen receptor that activates protein kinase A. Mol Pharmacol 51:605-612. Medline

Lewis MC, Gould TJ (2007) Reversible inactivation of the entorhinal cortex disrupts the establishment and expression of latent inhibition of cued fear conditioning in C57BL/6 mice. Hippocampus 17:462-470. CrossRef Medline

Lewis MC, Kerr KM, Orr PT, Frick KM (2008) Estradiol-induced enhancement of object memory consolidation involves NMDA receptors and protein kinase $\mathrm{A}$ in the dorsal hippocampus of female C57BL/6 mice. Behav Neurosci 122:716-721. CrossRef Medline

Li C, Brake WG, Romeo RD, Dunlop JC, Gordon M, Buzescu R, Magarinos AM, Allen PB, Greengard P, Luine V, McEwen BS (2004) Estrogen alters hippocampal dendritic spine shape and enhances synaptic protein immunoreactivity and spatial memory in female mice. Proc Natl Acad Sci U S A 101:2185-2190. CrossRef Medline

Luine VN, Jacome LF, Maclusky NJ (2003) Rapid enhancement of visual and place memory by estrogens in rats. Endocrinology 144:2836-2844. CrossRef Medline

Lüscher C, Huber KM (2010) Group 1 mGluR-dependent synaptic longterm depression: mechanisms and implications for circuitry and disease. Neuron 65:445-459. CrossRef Medline

Mao L, Yang L, Tang Q, Samdani S, Zhang G, Wang JQ (2005) The scaffold protein Homer $1 \mathrm{~b} / \mathrm{c}$ links metabotropic glutamate receptor 5 to extracellular signal-regulated protein kinase cascades in neurons. J Neurosci 25: 2741-2752. CrossRef Medline

Meitzen J, Mermelstein PG (2011) Estrogen receptors stimulate brain region specific metabotropic glutamate receptors to rapidly initiate signal transduction pathways. J Chem Neuroanat 42:236-241. CrossRef Medline

Meyers MJ, Sun J, Carlson KE, Marriner GA, Katzenellenbogen BS, Katzenellenbogen JA (2001) Estrogen receptor-beta potency-selective ligands: structure-activity relationship studies of diarylpropionitriles and their acetylene and polar analogues. J Med Chem 44:4230-4251. CrossRef Medline

Micevych P, Christensen A (2012) Membrane-initiated estradiol actions mediate structural plasticity and reproduction. Front Neuroendocrinol 33:331-341. CrossRef Medline

Micevych PE, Mermelstein PG (2008) Membrane estrogen receptors acting through metabotropic glutamate receptors: an emerging mechanism of estrogen action in brain. Mol Neurobiol 38:66-77. CrossRef Medline

Mikol DD, Hong HL, Cheng HL, Feldman EL (1999) Caveolin-1 expression in Schwann cells. Glia 27:39-52. CrossRef Medline

Milner TA, McEwen BS, Hayashi S, Li CJ, Reagan LP, Alves SE (2001) Ultrastructural evidence that hippocampal alpha estrogen receptors are located at extranuclear sites. J Comp Neurol 429:355-371. CrossRef Medline

Milner TA, Ayoola K, Drake CT, Herrick SP, Tabori NE, McEwen BS, Warrier S, Alves SE (2005) Ultrastructural localization of estrogen receptor beta immunoreactivity in the rat hippocampal formation. J Comp Neurol 491:81-95. CrossRef Medline

Mitterling KL, Spencer JL, Dziedzic N, Shenoy S, McCarthy K, Waters EM, McEwen BS, Milner TA (2010) Cellular and subcellular localization of 
estrogen and progestin receptor immunoreactivities in the mouse hippocampus. J Comp Neurol 518:2729-2743. CrossRef Medline

Mukai H, Tsurugizawa T, Murakami G, Kominami S, Ishii H, Ogiue-Ikeda M, Takata N, Tanabe N, Furukawa A, Hojo Y, Ooishi Y, Morrison JH, Janssen WG, Rose JA, Chambon P, Kato S, Izumi S, Yamazaki T, Kimoto T, Kawato S (2007) Rapid modulation of long-term depression and spinogenesis via synaptic estrogen receptors in hippocampal principal neurons. J Neurochem 100:950-967. CrossRef Medline

Naie K, Manahan-Vaughan D (2005) Pharmacological antagonism of metabotropic glutamate receptor 1 regulates long-term potentiation and spatial reference memory in the dentate gyrus of freely moving rats via $\mathrm{N}$-methyl-D-aspartate and metabotropic glutamate receptor-dependent mechanisms. Eur J Neurosci 21:411-421. CrossRef Medline

Neyman S, Manahan-Vaughan D (2008) Metabotropic glutamate receptor 1 (mGluR1) and 5 (mGluR5) regulate late phases of LTP and LTD in the hippocampal CA1 region in vitro. Eur J Neurosci 27:1345-1352. CrossRef Medline

Ogiue-Ikeda M, Tanabe N, Mukai H, Hojo Y, Murakami G, Tsurugizawa T, Takata N, Kimoto T, Kawato S (2008) Rapid modulation of synaptic plasticity by estrogens as well as endocrine disrupters in hippocampal neurons. Brain Res Rev 57:363-375. CrossRef Medline

Paxinos G, Franklin KBJ (2003) The mouse brain in stereotaxic coordinates, Ed 2. San Diego: Academic.

Phan A, Lancaster KE, Armstrong JN, MacLusky NJ, Choleris E (2011) Rapid effects of estrogen receptor $\alpha$ and $\beta$ selective agonists on learning and dendritic spines in female mice. Endocrinology 152:1492-1502. CrossRef Medline

Pompili A, Arnone B, Gasbarri A (2012) Estrogens and memory in physiological and neuropathological conditions. Psychoneuroendocrinology 37:1379-1396. CrossRef Medline

Qiu J, Bosch MA, Tobias SC, Grandy DK, Scanlan TS, Ronnekleiv OK, Kelly MJ (2003) Rapid signaling of estrogen in hypothalamic neurons involves a novel G-protein-coupled estrogen receptor that activates protein kinase C. J Neurosci 23:9529-9540. Medline

Qiu J, Bosch MA, Tobias SC, Krust A, Graham SM, Murphy SJ, Korach KS, Chambon P, Scanlan TS, Rønnekleiv OK, Kelly MJ (2006) A G-proteincoupled estrogen receptor is involved in hypothalamic control of energy homeostasis. J Neurosci 26:5649-5655. CrossRef Medline

Razandi M, Oh P, Pedram A, Schnitzer J, Levin ER (2002) ERs associate with and regulate the production of caveolin: implications for signaling and cellular actions. Mol Endocrinol 16:100-115. CrossRef Medline

Revankar CM, Cimino DF, Sklar LA, Arterburn JB, Prossnitz ER (2005) A transmembrane intracellular estrogen receptor mediates rapid cell signaling. Science 307:1625-1630. CrossRef Medline

Romano C, Sesma MA, McDonald CT, O’Malley K, Van den Pol AN, Olney JW (1995) Distribution of metabotropic glutamate receptor mGluR5 immunoreactivity in rat brain. J Comp Neurol 355:455-469. CrossRef Medline
Rong R, Ahn JY, Huang H, Nagata E, Kalman D, Kapp JA, Tu J, Worley PF, Snyder SH, Ye K (2003) PI3 kinase enhancer-Homer complex couples mGluRI to PI3 kinase, preventing neuronal apoptosis. Nat Neurosci 6:1153-1161. CrossRef Medline

Sheldahl LC, Shapiro RA, Bryant DN, Koerner IP, Dorsa DM (2008) Estrogen induced rapid translocation of estrogen receptor $\beta$, but not estrogen receptor $\alpha$, to the neuronal plasma membrane. Neuroscience 153:751-761. CrossRef Medline

Simonyi A, Schachtman TR, Christoffersen GR (2010) Metabotropic glutamate receptor subtype 5 antagonism in learning and memory. Eur J Pharmacol 639:17-25. CrossRef Medline

Stauffer SR, Coletta CJ, Tedesco R, Nishiguchi G, Carlson K, Sun J, Katzenellenbogen BS, Katzenellenbogen JA (2000) Pyrazole ligands: structureaffinity/activity relationships and estrogen receptor-alpha-selective agonists. J Med Chem 43:4934-4947. CrossRef Medline

Szego EM, Barabás K, Balog J, Szilágyi N, Korach KS, Juhász G, Abrahám IM (2006) Estrogen induces estrogen receptor alpha-dependent cAMP response element-binding protein phosphorylation via mitogen-activated protein kinase pathway in basal forebrain cholinergic neurons in vivo. J Neurosci 26:4104-4110. CrossRef Medline

Wade CB, Dorsa DM (2003) Estrogen activation of cyclic adenosine $5^{\prime}$ monophosphate response element-mediated transcription requires the extracellularly regulated kinase/mitogen-activated protein kinase pathway. Endocrinology 144:832-838. CrossRef Medline

Walf AA, Rhodes ME, Frye CA (2006) Ovarian steroids enhance object recognition in naturally cycling and ovariectomized, hormone-primed rats. Neurobiol Learn Mem 86:35-46. CrossRef Medline

Walf AA, Koonce CJ, Frye CA (2008) Estradiol or diarylpropionitrile administration to wild type, but not estrogen receptor beta knockout, mice enhances performance in the object recognition and object placement tasks. Neurobiol Learn Mem 89:513-521. CrossRef Medline

Waters EM, Mitterling K, Spencer JL, Mazid S, McEwen BS, Milner TA (2009) Estrogen receptor alpha and beta specific agonists regulate expression of synaptic proteins in rat hippocampus. Brain Res 1290: 1-11. CrossRef Medline

Zhao L, Brinton RD (2007) Estrogen receptor $\alpha$ and $\beta$ differentially regulate intracellular $\mathrm{Ca}^{2+}$ dynamics leading to ERK phosphorylation and estrogen neuroprotection in hippocampal neurons. Brain Res 1172:48-59. CrossRef Medline

Zhao Z, Fan L, Frick KM (2010) Epigenetic alterations regulate the estradiol-induced enhancement of memory consolidation. Proc Natl Acad Sci U S A 107:5605-5610. CrossRef Medline

Zhao Z, Fan L, Fortress AM, Boulware MI, Frick KM (2012) Hippocampal histone acetylation regulates object recognition and the estradiol-induced enhancement of object recognition. J Neurosci 32:2344-2351. CrossRef Medline 